OPEN ACCESS ISSN 2723-3774 (online)

Edited by:

Puspita Handayani

Reviewed by:

Khozin

${ }^{*}$ Correspondence:

Iwan Setiawan

iwan@unisayogya.ac.id

Received: 20 Desember 2019

Accepted: 5 Maret 2020

Published: 25 Agustus 2020

Citation:

Setiawan I (2020) Pluralitas Di

Perguruan Tinggi

Muhammadiyah/Aisyiyah dan Pemenuhan Spiritual Well - Being

Mahasiswa Non Muslim .

Journal of Islamic and

Muhammadiyah Studies. 1:2.

doi: 10.21070/jims.v1vi2i.1064
Pluralitas Di Perguruan Tinggi Muhammadiyah/Aisyiyah dan Pemenuhan Spiritual Well - Being Mahasiswa Non Muslim

\section{Plurality in Muhammadiyah/Aisyiyah College And Fulfillment of Spiritual Well-Being for Non-Muslim Students}

\author{
Iwan Setiawan*
}

Muhammadiyah / Aisyiyah College (PTMA) is a college that accepts students from various backgrounds, both Muslim and Non-Muslim (Catholic, Christian, Hindu and Buddhist). So it has an obligation to provide religious lessons for all students, both Muslims and Non-Muslims. In practice all students must take the Al-Islam and Kemuhammadiyahan (AIK) Courses. Non-Muslim students are also required to take AlK courses. Whereas Law Number 20 Year 2003 Article 12 Paragraph 1a explicitly states that education units have an obligation to provide religious subjects in accordance with the religion of the students. the same religion, In the implementation there are indeed problems in the practice of giving religious courses to non-Muslim students. Though students who have spiritual well-being or high spiritual well-being tend to have good spiritual. Giving religious subjects is one way to improve spiritual well-being.

Keywords: Non-Muslim Students, AIK Subjects, Solutions.

Perguruan Tinggi Muhammadiyah/Aisyiyah (PTMA) adalah perguruan tinggi yang menerima mahasiswa dari berbagai kalangan, baik Muslim ataupun non Muslim ( Katolik, Kristen, Hindu dan Budha). Sehingga memiliki kewajiban memberikan pelajaran keagamaan bagi seluruh mahasiswa, baik Muslim maupun non Muslim. Dalam praktiknya semua mahasiswa wajib menempuh Mata Kuliah Al-Islam dan Kemuhammadiyahan (AIK). Mahasiswa Non Muslim juga wajib mengambil Mata Kuliah AIK. Padahal UU Nomor 20 Tahun 2003 Pasal 12 Ayat 1a dengan tegas menyebutkan satuan pendidikan punya kewajiban untuk memberi mata pelajaran agama yang sesuai dengan agama yang dianut siswa "Setiap peserta didik pada setiap satuan pendidikan berhak mendapatkan pendidikan agama sesuai dengan agama yang dianutnya dan diajarkan oleh pendidikan yang seagama,". Dalam pelaksanannya memang ada masalah dalam praktik pemberian mata kuliah Agama bagi mahasiswa non Muslim. Padahal mahasiswa yang memiliki spiritual well-being atau kesejahteraan spiritual yang tinggi cenderung memiliki spiritual yang bagus. Pemberian Mata Kuliah Agama adalah salah satu cara meningkatkan kesejahteraan spiritual. 


\section{PENDAHULUAN}

Pendidikan memiliki peranan yang penting bagi pengembangan dan peningkatan mutu sumberdaya manusia. Sebagaimana ditulis dalam Undang-Undang Republik Indonesia Nomor 20 tahun 2003 tentang Sistem Pendidikan Nasional Pasal 1: Pendidikan adalah usaha sadar dan terencana untuk mewujudkan suasana belajar dan proses pembelajaran agar peserta didik secara aktif mengembangkan potensi untuk memiliki kekuatan spiritual agama, pengendalian diri, kepribadian, kecerdasan dan akhlak mulia, serta ketrampilan yang diperlukan dirinya, masyarakat, bangsa dan negara.

Salah satu dasar Pendidikan Nasional adalah pendidikan yang berakar pada nilai-nilai Agama. Sehingga pendidikan Agama wajib diajarkan kepada siswa. Agama memiliki peranan yang penting dalam mengembangkan dan meningkatan mutu sumber daya manusia. Sehingga pendidikan Agama diharapkan mampu meningkatkan spiritualitas dalam beragama. Dalam UU Sisdiknas Pendidikan Agama wajib diberikan kepada semua siswa, baik siswa di sekolah dasar, menengah dan atas. Juga mahasiswa di perguruan tinggi. Indonesia terdiri dari beragam Agama, sehingga pendidikan Agama menjadi tanggung jawab semua agama.

Di Indonesia pengelolaan Perguruan Tinggi dibagi menjadi 2, yaitu Perguruan Tinggi Negeri (PTN dan Perguruan Tinggi Swasta (PTS). PTN mengelola 54 Akademi, 133 Politeknik, 53 Sekolah Tinggi, 55 Insititut, 82 Universitas dan 7 Akademi. PTS mengelola 885 Akademi, 171 Politeknik, 2.445 Sekolah Tinggi, 171 Insititut, 552 Universitas dan 24 Akademi. forlap dikti (2018) Dari data diatas menunjukkan keterlibatan PTS dalam mencerdaskan kehidupan anak bangsa memiliki peranan yang signifikan. Jumlah PTS yang lebih banyak menunjukkan keterlibatan masyarakat dalam membantu pemerintah dalam mengelola pendidikan di Indonesia sungguh nyata.

Perguruan Tinggi Muhammadiyah dan Aisyiyah (PTMA) merupakan salah satu PTS berbasis Islam yang memiliki andil dalam mencerdaskan kehidupan bangsa. PTMA mengelola 18 Akademi, 4 Politeknik, 99 Sekolah Tinggi, 5 Insititut dan 48 Universitas. Muhammadiyah (????) Total ada 174 Perguruan Tinggi yang dikelola oleh Muhammadiyah. Semua PTMA menerima mahasiswa non Muslim. Kalau kita merunut sejarahnya, Kampus Muhammadiyah memang bersifat inklusif, bukan eksklusif. Artinya Kampus Muhammadiyah adalah lembaga pendidikan yang menerima semua mahasiswa dari berbagai kalangan.

Pluralitas Agama di Indonesia dan beragam suku bangsa menjadikan PTMA juga menerima mahasiswa yang beragam. Tahun 80an banyak siswa Muslim yang belajar disekolah Katolik, karena kualitas sekolah Katolik yang baik. Pada akhir-akhir ini gejala yang sebaliknya terjadi. Banyak siswa dan mahasiswa non Muslim yang kuliah dikampus Muhammadiyah, terutama di wilayah Timur Indonesia. Penelitian Abdul Mu'ti dan Fajar Riza Ul Haq Mu’thi (2007) menjelaskan bahwa banyak siswa non Muslim yang belajar disekolah Muhammadiyah. Terutama di sekolah dan kampus Muhammadiyah di Nusa Tenggara Timur (NTT), Papua dan Kalimantan Barat. Hal ini menunjukkan bahwa pluralitas bangsa Indonesia tidak hanya ditunjukkan dari beragam suku dan agama, tetapi telah diperkokoh oleh sistem sosial pendidikan yang membuka diri terhadap siswa-siswa non Muslim.

Dalam perkembangannya terjadi masalah berkaitan dengan pemberian mata pelajaran Agama. Di masa lalu Siswa Muslim yang sekolah di lembaga non Muslim wajib mengikuti Pelajaran Agama yang tidak dianutnya. Begitu juga mahasiswa non Muslim yang sekolah di lembaga Muslim wajib mengikuti Pelajaran Agama Islam. Perdebatan ini memuncak saat Dewan Perwakilan Rakyat (DPR) RI membahas UU Nomor 20 Tahun 2003 yang terkenal dengan sebutan UU Sisdiknas. Pasal 12 Ayat 1a dengan tegas menyebutkan satuan pendidikan punya kewajiban untuk memberi mata pelajaran agama yang sesuai dengan agama yang dianut siswa "Setiap peserta didik pada setiap satuan pendidikan berhak mendapatkan pendidikan agama sesuai dengan agama yang dianutnya dan diajarkan oleh pendidikan yang seagama,"

Terjadi pro dan kontra terhadap ayat ini. Yang pro berargumen perlunya diberikan pendikan agama sesuai dengan agama yang dianutnya. Sebahar menjelaskan Soebahar (2013) berkaca kepada kasus lembaga pendidikan Katolik/Kristen dimasa lalu yang tidak memberi pelajaran agama Islam kepada siswa yang beragama Islam. Yang kontra berargumen pasal tersebut tidak memperhatikan pluralitas atau keberagaman. Pada akhirnya ayat ini disahkan 
dalam UU Sisdiknas. Semangat pasal ini adalah pemberian kesejahteraan spiritual dengan pemberian mata pelajaran agama sesuai dengan agama yang dianutnya.

Setelah UU Sisdiknas berlaku apakah kewajiban pemberian mata pelajaran agama sesuai dengan agama yang dianut tiap siswa dilakukan? Ternyata tidak. Lembaga pendidikan swasta baik Muslim dan non Muslim mayoritas tidak melaksanakan perintah UU Sisdiknas. Dalam konteks otonomi sekolah, pada kenyataannya sekolah swasta berbasis keagamaan berhak menawarkan pelajaran agama sesuai dengan ciri khasnya. Seperti contoh sekolah Islam hanya mengajarkan Pelajaran Agama Islam. Sekolah Katolik hanya menawarkan Agama Katolik. Akan tetapi sekolah tidak berhak mewajibkan siswa-siswanya dari agama lain mengikuti pelajaran agama sesuai dengan ciri khas keagamaan sekolah yang bersangkutan.

\section{METODE}

Jenis penelitian ini termasuk penelitian pustaka (library research), yang mengkaji sumbersumber kepustakaan yang ada kaitanya dengan masalah pokok penelitian dan masalah yang telah dirumuskan . Sukandarrumidi (2012) Dalam library research ini, peneliti menggunakan penelitian deskriptif dengan lebih menekankan pada kekuatan analisis sumber dan data yang ada, dengan mengandalkan konsep yang ada untuk diinterpretasikan. Dimana untuk melengkapi data-data dalam penelitian menggunakan literatur (kepustakaan), baik berupa buku, catatan, maupun dokumen hasil penelitian dari penelitian terdahulu.

\section{HASIL DAN PEMBAHASAN}

Indonesia adalah negara yang Pluralis. Indonesia terdiri dari beratus suku dan etnis. Menurut Biro Data Statistik (BPS,2010) Total jumlah etnis dan subetnis berjumlah 1340. Komposisi etnis terbesar dengan jumlah lebih dari satu juta adalah Jawa (95.285.500), Sunda (36.778.404), Batak (8.546.040), Madura (7.271.727), Betawi (6.276.440), Minangkabau (6.575.145), Bugis (6.241.688), Melayu (5.310.421), Arab (5.013.162), Banten (4.696.273), Banjar (4.127.525), Bali (3.911.059), Sasak (3.190.102), Dayak (3.090.122) Tionghoa (2.830.322) Makkar (2.723.544) Cirebon (1.932.377).

Indonesia juga mengakui pemeluk agama dan kepercayaan yang berbeda-beda. Berdasarkan Sensus Penduduk tahun 2010 (BPS,2010),jumlah pemeluk Agama adalah sebagai berikut: Islam (207.176.162), Kristen (16.528.513), Katolik (6.907.873) Hindu (4.012.116), Budha (1.703.254), Konghucu ( 117.091) lainnya (229.617) Indonesia adalah bangsa yang religius. Dalam UUD 1945 pasal 29 disebutkan "Negara berdasarkan pada Ketuhanan Yang Maha Esa". Pasal ini dijadikan sebagai nilai dasar dalam bernegara. Tetapi Indonesia bukan negara agama (non-theocratic state). Indonesia adalah bangsa yang disatukan oleh ideologi Pancasila. Pancasila oleh Nurcholish Madjid dianalogikan seperti "Piagam Madinah" dimana terjadi kesepakatan ideologi bersama antar umat beragama yang bergabung ke dalam Negara Kesatuan Republik Indonesia. Kesepakatan ini diwujudkan dalam Ideologi Pancasila. Pancasila adalah Kalimatu Sawa' atau titik pertemuan semua kelompok yang membentuk Bangsa ini, dimana Pancasila adalah ide dan prinsip yang menyatukan semua golongan. Umat Islam secara mayoritas menerima Pancasila sebagai Ideologi bersama. Pertimbangan penerimaan Pancasila bagi umat Islam antara lain, pertama nilai-nilai Pancasila dibenarkan oleh ajaran Islam dan tidak ada pasal yang menyelisi nilai-nilai Islam, kedua, fungsi Pancasila sebagai nuktah-nuktah kesepakatan antar berbagai golongan untuk mewujudkan kesatuan politik bersama. Madjid (1999)

Melalui proses akomodasi, akulturasi dan alamiah pluralitas Agama dan budaya membentuk karakter bangsa yang toleran dan terbuka. Mayoritas penduduk Indonesia adalah Islam, tetapi trade mark budaya Indonesia warisan Hindu dan Budha seperti Borobudur dan Prambanan. Walaupun ada gejala naiknya intoleransi dalam hal Agama, mayoritas Muslim Indonesia adalah moderat. Abdul Mu'ti mengutip Rand Corporation menjelaskan Islam Moderat memiliki empat karakteristik. Pertama, menerima sistem demokrasi untuk memilih pemimpin dan wakil rakyat. Kedua, menerima hukum positif negara yang non sektarian, dalam pengertian tidak 
mendukung penerapan Syariat Islam dalam hukum dan politik. Ketiga, menghormati hak-hak perempuan dan kaum minoritas agama. Keempat, menentang terorisme dan tindak kekerasan yang melanggar hukum. Mu'ti and Ali (2016)

Di ranah pendidikan semangat pendidikan yang toleran dan terbuka menjadi ciri khas pendidikan di Indonesia. Di Indonesia lembaga pendidikan memiliki sejarah yang panjang. Sebelum Indonesia merdeka lembaga pendidikan yang dikelola oleh kelompok Islam Steenbrink (1986) dan jaringan Katolik/Kristen Coedes (2015) sudah sudah eksis mendidikan anak bangsa. Bahkan jauh sebelumnya lembaga pendidikan Hindu dan Budha Coedes (2015) telah menancapkan jaringan keilmuannya ke pelosok Asia Tenggara. Setelah Indonesia merdeka lembaga pendidikan dikelola oleh negara dan swasta. Kedua lembaga ini sama-sama bertujuan untuk mencerdaskan anak bangsa. Jenjang pendidikan dimulai dari PAUD, Pendidikan Dasar, Menengah, Atas dan Perguruan Tinggi.

Alwi Shihab Sihab (1998) menjelaskan berkaitan dengan pengertian pluralisme yang sering disalahpahani oleh mayoritas masyarakat. Pertama, Pluralisme adalah keterlibatan aktif dalam memahami kemajemukan dalam beragama. Tiap pemeluk agama dituntut bukan saja mengakui keberadaan dan hak agama lain, tetapi berusaha memahami perbedaan dan persamaan guna tercapainya kerukunan dan kebhinekaan. Kedua, Pluralisme harus dibedakan dengan kosmopolitanisme. Kosmopolitanisme menunjukkan pada realitas keragaman agama, ras dan bangsa dalam satu lokasi. Pluralisme adalah interaksi manusia yang berbeda agama, ras dan bangsa sehingga terwujud dialog saling memahami. Ketiga, Konsep pluralisme tidak dapat disamakan dengan relativisme yang menyatakan semua agama itu benar. Konsep Pluralisme menghindari sikap absolutisme dan menghakimi atas kepercayaan yang berbeda dengan yang dianutnya. Keempat, konsep Pluralisme bukan sinkretisme, yaitu menciptakan suatu agama baru dengan memadukan unsur tertentu atau sebagaian komponen untuk dijadikan satu menjadi agama baru.

Muhammmadiyah sebagai gerakan Islam terbesar di Indonesia, tentunya tidak menutup mata dengan pluralitas yang ada. Sebagai organisasi pergerakan Islam tentunya Muhammadiyah tidak hanya mengatur tata cara ibadah namun juga hubungan muamallah dengan sesama umat Islam maupun dengan non Islam. Dalam kaitannya dengan persinggungan Muhammadiyah dengan kelompok lain, dalam sejarahnya, organisasi ini berupaya untuk membendung misi Kristenisasi di Indonesia.

Muhammadiyah secara terbuka berupaya menanggulangi pasang naik kegiatan missionaries Kristen dengan berbagai cara. Tujuan ini dicapai, dengan cara-cara langsung, namun lebih sering kepada cara yang tidak langsung seperti dengan menyediakan fasilitas pendidikan dan kesehatan Islam. Janiru Jainuri (2002) menjelaskan cara ini berupaya untuk menandingi fasilitas yang sudah mapan dikembangkan lembaga missionaries Kristen. Achmad Jainuri menjelaskan sikap Inklusifitas Muhammadiyah, adalah terletak bagaimana Muhammadiyah mensikapi realitas pluralitas yang ada untuk saling berlomba-lomba dalam kebajikan. Pluralitas adalah sebagai suatu realitas dari Tuhan, dimana Tuhan tidak menghendaki adanya monolitisme umat manusia.

Dalam permasalahannya dengan realitas pluralitas, Muhammadiyah pada masa awal mampu menunjukkan arah gerakan pembaharu. Muhammadiyah mampu mendobrak pemahaman-pemahaman Islam konservatif, pada masanya. Muhammadiyah mampu diterima, diberbagai kalangan dikarenakan sikap terbukanya terhadap golongan yang berbeda.

Abdul Mu'ti menjelaskan akar pluralisme di sekolah Muhammadiyah sudah terjalin sejak lama. Dimulai dari paham ideologi Muhammadiyah yang didasarkan oleh Al-Qur'an dan Sunnah Maqbullah. Lalu dipraktikkan dalam keseharian. Ideologi Muhammadiyah yang tertulis dalam Matan Keyakinan dan Cita-Cita Hidup Muhammadiyah (MKCH) yang menjunjung nilai toleransi dalam beragama. Keterbukaan Kiai Haji Ahmad Dahlan dalam bergaul dan berdialog dengan orang yang berbeda agama juga menunjukkan toleransi yang kuat dalam Muhammadiyah. Dalam praktiknya sekolah Muhammadiyah tidak menolak siswa dan mahasiswa Non Muslim sekolah di Muhammadiyah. Catatan penting dari penelitian Mu'ti adalah Muhammadiyah bukan organisasi yang eksklusif, tetapi organisasi yang inklusif.

Sehingga pemenuhan kebutuhan spiritual bagi mahasiswa di PTMA sangat penting. Mohammad Mozafari Makki Abadi yang menunjukkan adanya hubungan yang positif antara 
pemenuhan Spiritual Well Being dengan prestasi akademik mahasiswa. Prestasi Akademik mahasiswa yang religius, memiliki hubungan antar individu yang baik ternyata memiliki nilai akademik yang baik. Spiritual Well Being menjadi predictor dalam mencapai nilai akademik yang baik. Spiritual Well Being yang tinggi akan memberikan rasa kenyamanan, kebagahiaan, cinta dan sikap positif dalam diri mahasiswa. Dengan kondisi inilah prestasi mahasiswa akan tinggi.

Well Being atau dikenal dengan kesejahteraan merupakan konsep yang umum dalam ilmu psikologi. Sejahtera adalah kondisi yang serba baik, masyarakatnya dalam keadaan makmur, sehat dan damai. Deci \& Ryan Deci and Ryan (2008) menjelaskan konsep well being berasal dari dua aliran filsafat yaitu hedonia dan eudonomia. Pendekatan hedonia atau hedonis mempersepsikan kesejahteraan secara subjektif, sehingga well being dianggap sama dengan kebahagiaan. Tujuan utamanya adalah untuk mencapai kenikmatan atau kebahagiaan dan menghindari rasa sakit, sehingga menimbulkan well being yang bersifat sementara.

Pandangan hedonik memandang well-being sebagai pemenuhan kebutuhan-kebutuhan individu dengan memaksimalkan emosi positif dan mengurangi atau menghindari emosi negatif. Maka orang yang sedang dalam kondisis bahagia akan memaksimalkan emosi positif dan meminimalkan emosi negatif. Huta Huta (2005) menjelaskan pendekatan ini memungkinkan individu untuk menilai apa yang dianggap penting untuk bisa merasa bahagia dalam kehidupan mereka. Huta menjelaskan Konten pendekatan hedonic digambarkan sebagai hedonic experiences yang terdiri dari perasaan positif, kepuasan, kegembiraan dan menurunnya perasaan negatif. Para ahli psikologi yang mengikuti pendekatan hedonic menganggap bahwa well-being merupakan kebahagiaan subjektif. Oleh karena itu sebagian peneliti menggunakan pengukuran subjective well-being sebagai pengukuran kebahagiaan dengan menggunakan dimensi kepuasan hidup, perasaan positif dan tidak adanya perasaan negatif. Dimensi inilah yang dijadikan dasar untuk mengukur subjective well-being

Selanjutnya, pendekatan eudaimonik memandang hidup memiliki makna yang ditandai dalam pemuasan kebutuhan diri. Pendekatan ini mendefinisikan well-being tercapai jika seseorang menjadi pribadi yang sepenuhnya berfungsi. Berdasarkan pendekatan ini maka Ryff and Keyes (1995) memunculkan istilah psychological well-being, yang berarti bahwa orang mencapai well-being jika memiliki tujuan hidup, menyadari potensi diri, memiliki hubungan yang berkualitas dengan orang lain, dan merasa bertanggung jawab atas kehidupannya sendiri. Dari perspektif teori ini, kesejahteraan cenderung dilihat sebagai munculnya atribut diri yang positif. Deci \& Ryan menjelaskan Eudaimonia tercapai apabila perilaku manusia sesuai dengan nilainilai yang diyakini.

Ryff Ryff (1989) menjelaskan dimensi-dimensi psychological well being terdiri dari penerimaan diri, hubungan positif dengan orang lain, kemandirian, penguasaan lingkungan, tujuan hidup dan pertumbuhan pribadi. Individu yang memiliki penerimaan diri baik ditandai dengan memiliki sikap positif terhadap diri sendiri, mengakui dan menerima banyak aspek diri sendiri baik yang kualitas baik maupun buruk, memiliki pandangan positif terhadap kehidupan kehidupan masa lalu. Individu yang memiliki hubungan positif dengan orang lain ditunjukkan dengan kemampuan menjalin hubungan yang hangat, memuaskan, memiliki kepercayaan terhadap orang lain, memiliki perhatian terhadap kesejahteraan orang lain, memiliki empati, kasih sayang, dan keintiman yang kuat dan mampu memberi dan menerima hubungan dengan sesama. Individu yang memiliki kemandirian adalah individu yang mampu menentukan nasib sendiri, mampu menahan tekanan sosial untuk berpikir dan bertindak dengan cara tertentu, mengatur perilaku dari dalam diri sendiri, mampu mengevaluasi diri dengan standar pribadi. Sedangkan individu yang memiliki kemampuan mengelola lingkungan akan mampu mengelola peluang yang ada disekitanya dan berkreasi sesuai dengan kebutuhan pribadi. Individu yang memiliki tujuan hidup memiliki rasa rasa keteraturan, merasa ada makna untuk kehidupan sekarang dan masa lalu, memiliki keyakinan terhadap yang memberi tujuan hidup dan sasaran untuk hidup. Selanjutnya, individu yang memiliki pertumbuhan pribadi memiliki orientasi hidup berkelanjutan, melihat diri sebagai diri yang bisa tumbuh dan berkembang, dan terbuka menerima pengalaman baru, menyadari potensinya, mengalami peningkatan dari waktu ke waktu dengan menggunakan potensinya.

Spiritul Well Being atau kesejahteraan spiritual berasal dari dua kata kesejaheteraan dan spir- 
itual. Jalaludin menjelaskan Spiritual atau spiritualitas berasal dari kata latin spirit atau spiritus yang berarti nafas. Sedangkan spirare berarti bernafas, artinya hidup butuh bernafas, memiliki nafas artinya memiliki spirit. Beberapa kunci yang mengacu kepada spiritualitas yaitu: makna ( meaning), nilai-nilai (value), transendensi (trancendency), bersambung (connecting) dan menjadi (becoming).

Spiritual merujuk Kamus Besar Bahasa Indonesia (KBBI) artinya adalah berhubungan dengan atau bersifat kejiwaan (rohani, batin), spiritual merupakan kebangkitan atau pencerahan diri dalam mencapai tujuan dan makna hidup serta merupakan bagian paling pokok dari keseluruhan kesehatan dan kesejahteraan seseorang . Jalaludin (2012) Spiritualitas merupakan bentuk habluminallah (hubungan manusia dengan Allah) bagi umat Islam diwujudkan dengan Sholat, Puasa, Zakat dan segala bentuk ibadah lainnya. Secara garis besar spiritualitas merupakan kehidupan rohani (spiritual) dan terwujud dalam cara berpikir, merasa, berdoa dan berkarya.

piritualitas telah menjadi bagian dari sejarah kehidupan manusia. Zinnbauer dan Pargament menjelaskan keduanya telah menjadi subjek dan objek dari seni, musik, puisi, budaya, dan aktivitas manusia lainnya Wong (2014) . Namun, pada awalnya sisi ilmiah Religiusitas dan Spiritualitas masih tergolong baru dalam bidang psikologi. Hal ini terjadi karena pada awalnya menurut terdapat pandangan bahwa Agama/ piritualitas tidak dianggap sebagai bidang penelitian psikologi. Padahal aspek spiritual sebenarnya adalah salah satu kebutuhan manusia yang mendasar. Kemudian muncul masa dimana para positivist, mengkaji mengenai konstruk seperti agama, spiritualitas, dan spiritual well-being dan terus berkembang hingga konstruk ini menjadi bagian dari kajian positive psychology.

Menurut Paloutzian Wong (2014) spiritual well-being mencerminkan kebahagiaan individu yang mencakup dua area, yaitu kedekatan dengan Tuhan dan manifestasinya dalam kehidupan berupa dimilikinya kehidupan yang bermakna. Wong menjelaskan bahwa spiritual wellbeing merupakan sebuah kondisi yang memiliki dua status, yaitu (1) dimensi vertikal yang menunjuk pada kesejahteraan (well-being) pada hubungannya dengan Tuhan atau kekuatan yang lebih besar (higher power) yang mengarah pada elemen religius, dan (2) dimensi horizontal yang menunjuk pada tujuan dan kepuasan hidup yang mengarah pada makna hidup. Monali D Mathad menjelaskan secara umum, spiritual well-being memiliki korelasi positif dengan tujuan hidup, self Compassion, dan satisfaction.

Pendapat lain mengatakan bahwa spiritualitas sebagai prinsip hidup untuk menemukan makna dan tujuan hidup serta hubungan dengan yang maha Tinggi. Spiritualitas merupakan bentuk dari motivasi instrinsik yang menguatkan, mendorong dan memilih tingkah laku manusia, bahkan untuk memaknai hidup setelah mati. Dari berbagai definisi, inti dari spiritualitas adalah mengarah pada tujuan hidup, hubungan positif dan pemaknaan hidup.

Selanjutnya Hasan menjelaskan dimensi-dimensi spiritualitas adalah memiliki gairah hidup, peduli, kasih sayang, hasrat, empathi, harapan, harmoni, kegembiraan, cinta, rasa hormat, sensitivitas, toleransi, dan kerelaan. Selanjutnya bidang kajian spiritualitas terdiri dari spiritualitas murni dan spiritualitas terapan. Spiritualitas murni mengkaji pengalaman transcendental individu yang paling dalam, sedangkan spiritualitas terapan mengkaji variabel-variabel fisiologis, psikologis, organisasional, dan sosial sebelum dan sesudah realitas transedental Hasan (2010)

Berdasarkan pendekatan tersebut, maka muncul beberapa ciri pribadi yang memiliki dimensi spiritualitas yang baik. Lebih jelasnya dapat dilihat dalam tabel berikut :

Dalam penelitian Najmeh Jafari adanya peningkatan spiritual well-being dapat meningkatkan kualitas hidup mereka. Mohammad Mozafari Makkai Abadi juga menjelaskan adanya spiritual well-being yang tinggi dapat menghubungkan dengan pencarian jati diri mahasiswa terhadap tujuan hidup mereka. Mahasiswa yang terpenuhi kebutuhan spiritualnya cenderung memiliki prestasi yang baik. Mahasiswa yang terpenuhi kebutuhan spiritualnya memiliki semangat belajar yang baik, karena memiliki motivasi berkaitan dengan tujuan hidupnya. Pemberian mata kuliah Agama salah satu cara untuk meningkatkan spiritual wellbeing.

Ketika mahasiswa non Muslim yang kuliah di PTMa dan mengikuti mata kuliah AIK, apa mereka memperoleh spiritual well-being? Pertanyaan inilah yang perlu mendapatkan jawaban. 
TABLE 1 | Bidang Kajian Spiritualitas

\begin{tabular}{|c|c|}
\hline Pendapat Pakar & Dimensi Spiritualitas \\
\hline $\begin{array}{l}\text { Spiritual Well Being } \\
\text { (Paloutzian, 2002) }\end{array}$ & $\begin{array}{l}\text { Kedekatan dengan Tuhan dan manifestasinya dalam kehidu- } \\
\text { pan berupa dimilikinya kehidupan yang bermakna. }\end{array}$ \\
\hline $\begin{array}{l}\text { Spiritual well-being } \\
\text { (Wong, 2014) }\end{array}$ & $\begin{array}{l}\text { Dimensi vertikal yang menunjuk pada kesejahteraan (well- } \\
\text { being) pada hubungannya dengan Tuhan atau kekuatan yang } \\
\text { lebih besar (higher power) yang mengarah pada elemen } \\
\text { religius, dan dimensi horizontal yang menunjuk pada tujuan } \\
\text { dan kepuasan hidup yang mengarah pada makna hidup }\end{array}$ \\
\hline $\begin{array}{l}\text { Spiritual well-being } \\
\text { (Hasan, 2010) }\end{array}$ & $\begin{array}{l}\text { Memiliki gairah hidup, peduli, kasih sayang, hasrat, empathy, } \\
\text { harapan, harmoni, kegembiraan, cinta, rasa hormat, sensitivi- } \\
\text { tas, toleransi, dan kerelaan }\end{array}$ \\
\hline
\end{tabular}

Pemenuhan spiritual well-being penting bagi mahasiwa. Selain merupakan hak dasar mahasiswa dalam beragama, mahasiswa yang memiliki spiritual well-being yang tinggi cenderung memiliki prestasi yang baik. Dengan mengetahui pemenuhan spiritual well- being mahasiswa.

\section{KESIMPULAN}

Dalam kondisi seperti inilah perlunya pemikiran untuk tetap memberi pemenuhan spiritual well-being bagi mahasiswa non Muslim yang belajar di di PTMA. Majelis Diktilitbang PP Muhammadiyah sebagai lembaga pemangku kebijakan pendidikan Tinggi di Muhammadiyah beberapa kali mengadakan workshop berkaitan dengan pemenuhan kebutuhan spiritual mahasiswa non Muslim. Salah satunya adalah ide Mata Kuliah Al Islam dan Kemuhammadiyahan (AIK) bagi mahasiswa non Muslim. Langkah maju ini patut didukung sebagai upaya untuk memenuhi spiritual well-being mahasiswa non Muslim di PTMA.

Kebijakan PTMA yang inklusif dengan menerima mahasiswa non Muslim patut mendapat apresiasi. Tentu ada konsekwensi berkaitan dengan pemenuhan kewajiban memberikan pendidikan Agama. Pada saat ini kebijakan PTMA sama dengan kebijakan Perguruan Tinggi Swasta berbasis Agama. Yaitu tetap memberikan pelajaran Agama sesuai dengan kekhasan lembaganya. PTMA juga memberikan pendidikan Agama Islam kepada semua mahasiswa. Tentu bagi non Muslim yang kuliah di PTMA tidak ada paksaan untuk mengikutinya. Yang masih menjadi pekerjaan rumah adalah pemenuhan spiritual well being mahasiswa non Muslim yang kuliah di PTMA perlu mendapat perhatian yang serius.

\section{UCAPAN TERIMA KASIH}

enulis mengucapkan terima kasih kepada panitia Seminar Nasional AIK diUniversitas Muhammadiyah Sidoarjo (UMSIDA). Semoga paper ini dapat menjadi tambahan referensi bagi Muhammadiyah khususnya, dan pendidikan Muhammadiyah umumnya. Masih banyak pekerjaan rumah berkaitan dengan pengembangan Mata Kuliah AIK dimasa sekarang dan dimasa datang

\section{REFERENCES}

Coedes, G. (2015). Kedatuan Sriwijaya (Bandung: Mizan).

Deci, E. L. and Ryan, R. M. (2008). Hedonia, eudaimonia, and well-being: an introduction. Journal of Happiness Studies 9, 1-2.

forlap dikti (2018). data perguruan tinggi . https://forlap. ristekdikti.go.id/perguruantinggi/homegraphpt.

Hasan (2010). Spiritualitas dalam Perilaku Organisasi. vol. 7 (Science Publications).

Huta, V. (2005). An overview of hedonic and eudaimonic well-being concepts. In An overview of hedonic and eudaimonic well-being concepts, ed. L. R. M. B. Oliver (New York:
Routledge).

Jainuri, A. (2002). Ideologi Kaum Reformis:Melacak Pandangan Keagamaan Muhammadiyah Periode Awal. In Ideologi Kaum Reformis:Melacak Pandangan Keagamaan Muhammadiyah Periode Awal (Surabaya: .LPAM).

Jalaludin (2012). Agama Psikologi (Jakarta: Rajawali).

Madjid, N. (1999). Cita-Cita Politik Islam Era Reformasi (Jakarta: Paramadina).

Muhammadiyah, S. (????). Daftar Perguruan Tinggi Muhammadiyah Aisyiyah. http://www.suaramuhammadiyah. id/2018/11/23/daftar-perguruan-tinggimuhammadiyahdan-aisyiyah-2018/.

Mu’thi (2007). Kristen Muhammadiyah. 
Mu’ti and Ali (2016). Akar Pluralisme dalam Pendidikan Muhammadiyah. Jurnal Afkaruna 12.

Ryff, C. D. (1989). Happiness is everything, or is it? Explorations on the meaning of psychological well-being. Journal of Personality and Social Psychology 57, 1069-1081. doi: 10.1037/0022-3514.57.6.1069.

Ryff, C. D. and Keyes, C. L. M. (1995). The structure of psychological well-being revisited. Journal of Personality and Social Psychology 69, 719-727. doi: 10.1037/0022-3514.69. 4.719 .

Sihab, A. (1998). Islam Inklusif: Menuju Sikap Terbuka dalam Beragama (Bandung: Mizan)

Soebahar, A. H. (2013). Kebijakan Pendidikan Islam dari Ordonansi Guru sampai UU Sisdiknas. In Kebijakan Pendidikan Islam dari Ordonansi Guru sampai UU Sisdiknas (Jakarta: Rajawali)

Steenbrink, K. A. (1986). Pesantren, Madrasah, Sekolah: Pendidikan Islam dalam Kurun Modern.

Sukandarrumidi (2012). Metodologi Penelitian (Yogyakarta: UGM Press).
Wong, P. (2014). The Positive Psychology of Meaning in life and well-being" dalam AC Michallos ed, Encyclopedia of quality of life and well-being research (New York: Springer)

Conflict of Interest Statement: The author declare that the research was conducted in the absence of any commercial or financial relationships that could be construed as a potential conflict of interest.

Copyright (c) 2020 Setiawan. This is an open-access article distributed under the terms of the Creative Commons Attribution License (CC BY). The use, distribution or reproduction in other forums is permitted, provided the original author(s) and the copyright owner(s) are credited and that the original publication in this journal is cited, in accordance with accepted academic practice. No use, distribution or reproduction is permitted which does not comply with these terms. 